DOI https://doi.org/10.30525/978-9934-26-039-1-53

\title{
SEMANTIZATION OF PROPER NAMES IN A LITERARY WORK
}

\author{
Shotova-Nikolenko A. V. \\ Candidate of Philological Sciences, Associate Professor, \\ Senior Lecturer at the Department of Foreign Languages \\ Odesa State Environmental University \\ Odesa, Ukraine
}

In the poetonymosphere of a literary work, three layers of proper names can be distinguished: 1) ordinary, the real names of which are required by the subject of depiction; 2) unusual names that are absent in everyday life, but which are needed by the figurative system of the literary work and by the creative search of the author [4: 284]; 3) culturally significant names that are the key to world and national culture, correlated with a particular historical epoch [6:39], reflecting the real historical time and space in a literary work. Such proper names have a special cultural and national significance, existing in a certain mythological and cultural situation, in oral and written text or simply in a well-known context. Considering the functioning of onyms in a literary work, it can be stated that the processes of their figurative semantics are based on ethnocultural concepts and reflect a certain historical or nationalcultural situation, and are subjected to certain principles of poetics.

Proper names (both national and universal) always play a certain role, they are an additional means of realization of the creative author's idea, which have the following cases of their implementation in the text: 1) proper names of the language create a natural, national, local coloring in the work, and at the same time they are onyms of the native language spoken by the writer. Leaving the ancestral castle, where he spent his unforgettable childhood, G. Byron created the poem «On Leaving Newstead Abbey» (1803). In this work, shrouded in a romantic-heroic haze, the poet depicts the heroic deeds of his Anglo-Saxon ancestors over a long historical period, and accordingly uses genetically English anthroponyms: John of Haristan, Paul, Hubert, Edward, Rupert, Robert, Henry, Mary and toponyms: Newstead, England, Marston, Sherwood [9]; 2) proper names from the language system of another language, i.e. foreign language onymia, which creates the appropriate national, local and place coloring of the work in accordance with the writer's creative intention for greater authenticity of the depicted events. Thus, in the poem «Beppo» (1817), where the action takes place in Italy, there are Italian anthroponyms Laura, Beppo (is a short form of name Giuseppe); toponyms the Rialto (bridge 
in Venice), Ridotto (hall for concerts and masquerades in Venice), Manfrini's palace and urbanonyms Venice, Florence, Verona, Rome [9]; 3) the precedent proper names, which are a kind of onyms-identifiers of the corresponding historical time, period, epoch. In the context of the poem, such names (names of historical persons) can belong to both plot and non-plot characters: writers Goldoni, Walter Scott, Tomas Moor, Samuel Rogers, artists Raphael, Canova, Titian, Giorgione; political and military figures of G. Byron's time: Romilly, Wilberborce, Napoleon («Beppo») [9]; Charles I, Falkland, Henry II, Henry VIII («Elegy On Newstead Abbey») [9]. As for 4) author's innovations by G. Byron should distinguish the comic pseudonym Botherby (to bother by from English language - to disturb) («Beppo»). As it is noted, «The authors also turn to the easy modification of surnames and literary names of historical persons when using these names for their own purposes. Sometimes it is a hint of a certain personality, in other cases the purpose of such a change is relevance to time, and in a humorous work - it is ridicule of a certain historical person [2:43]. Thus, in this way, Byron ironizes his contemporary, the English poet and translator William Sotheby (William Sotheby, 1757-1833), author of «The Five Tragedies» and other very mediocre his works [1: 525]: No bustling Botherby have they to show'em // That charming passage in the last new poem... [9: 413].

G. Byron also addressed to 5) unusual proper names in his romantic writings. For example, the lyrical poems of the London period of the artist are united under the mysterious name «To Thyrza» («To Thyrza») [8], dedicated, according to researchers of Byron's literary heritage, to the hidden love of the poet who died in young age. In this lyrical work, the poet gave her a Greek name - Thyrza [8: 472], which is taken from the poem of the Swiss poet S. Gesner (1730-1788) «Death of Abel» (1758) [3: 729]. The anthroponym Thyrza has an unusual sound and shape (from the Greek language - thyrsos «a flower-wrapped rod of ivy or vine, worn during the holidays» [7: 392] and fully corresponds to the poetry of the symbolic and romantic direction.

Thus, the poetonymicon (the system of proper names) of any literary work creates corresponding time and space and reflects the active memory of the author: history, culture, geography exist in the individual images of the artist [5: 173]. G. Byron creates original onymic space (poetonymosphere) in his romantic poetic works, where the national (English-language proper names) and universal (foreign-language proper names) interact in a balanced and harmonious way, relevant to the texts of the works and pragmatically refer to the recipient depending on the creative directions and author's conception. 


\title{
Література:
}

1. Демурова Н. Комментарий / Selections from Byron. Москва, 1973. Р. 449-526.

2. Зайцева К. Б. Английская стилистическая ономастика: Тексты лекций. Одесса, 1973. 67 с.

3. Зорин А. Л. Комментарии / Дж. Г. Байрон. Избранная лирика. Москва, 2004. С. 705-767.

4. Карпенко Ю. А. Ономастический компонент стихотворений М. Ю. Лермонтова. Літературна ономастика: збірник статей / Карпенко О. Ю. Одеса: Астропринт, 2008. С. 282-285.

5. Ревзина О.Г. Собственные имена в поэтическом идиолекте М. Цветаевой. Поэтика и стилистика: 1988-1990. М.: Наука, 1991. С. 172-192.

6. Смольников С. Н., Яцкевич Л. Г. На золотом пороге немеркнущих времен: Поэтика имен собственных в произведениях Н. Клюева. Вологда, 2006. 262 с. 7. Трійняк I. І. Словник українських імен. К.: «Довіра», 2005. 509 с.

7. Усі зарубіжні письменники / упоряд. О. Д. Міхільов та ін. Харків: ТОРСІНГ ПЛЮС, 2006. 384 c.

8. Byron D. G. Selections from Byron. M.: Progress Publishers, 1973. $526 \mathrm{p}$.

DOI https://doi.org/10.30525/978-9934-26-039-1-54

\section{ПРОВЕДЕННЯ ІНФОРМАЦІЙНОЇ ВІЙНИ РR СЛУЖБАМИ}

\author{
Шугаєв А. В. \\ кандидат філологічних наук, \\ старший викладач кафедри англійської філологї̈ та перекладу \\ Житомирського державного університету імені Івана Франка \\ м. Житомир, Украӥна
}

Розглядаючи сутнісні характеристики інформаційної війни, необхідно зупинитися на діяльності PR агенцій та їх ролі як медіатора прихованого, а іноді відкритого агресивного впливу. Середовищем для такого впливу виступає сучасний інтернет-дискурс. Технології інтернет мережі настільки еволюціонували, що користувач, в інформаційну епоху, отримав можливість створювати контент, а не лише змогу користуватися онлайн інформацією. У свою чергу, PR служби різних країн 